\title{
Lactose intolerance and cow's milk protein allergy
}

\author{
Adriano Henrique do Nascimento RANGEL ${ }^{1}$, Danielle Cavalcanti SALES ${ }^{1}$, Stela Antas URBANO ${ }^{1 *}$, \\ José Geraldo Bezerra GALVÃO JÚNIOR², Júlio César de ANDRADE NETO ${ }^{1}$, Cláudia de Souza MACÊDO ${ }^{1}$
}

\begin{abstract}
Adverse reactions to food intake have very diverse etiology and symptomatology. Regarding milk, its food allergy is presented as lactose intolerance, the sugar in milk, or allergy to milk protein. Despite having different symptomatology, confusions among allergic conditions to dairy and its mediators are common. Milk protein allergy originates from protein components present in milk, causing reactions to either the protein fractions in emulsion (caseins) or in whey (milk albumin). The allergic reaction is type IV mediated by T lymphocytes. The allergic reaction produces severe cellular damage and it triggers physical, mental and emotional symptomatology that may vary in time, intensity and severity. Lactose intolerance is originated by total or partial absence of the enzyme that digests this disaccharide. Lactose intolerance can be primary or congenital and secondary; the former being more rare and severe, the latter being more common. Lactase deficiency can be diagnosed by symptoms associated with cramping and diarrhea. Thus, the objective of this study was to conduct a review of available literature on cow's milk protein allergy and lactose intolerance.
\end{abstract}

Keywords: cow's milk; adverse reactions to food; immune response.

Practical Application: Know and differentiate lactose intolerance and allergy to cow’s milk protein.

\section{Introduction}

Successive changes in eating patterns have triggered serious changes in the quality of life of human populations. The ease of obtaining food associated with excess calories has made diseases associated with overweight - hypercholesterolemia, dyslipidemia, hypertension, and diabetes - more prevalent. Nutritional allergies are also associated with the improvement of food standards, with more reoccurring due to the global population's access to different types of food.

Due to its nutritional quality, milk - a product secreted by the mammary glands of female mammals in postpartum - is an important food source. Milk and milk product intake is associated with better diet quality and has been associated with a reduced risk of chronic diseases or conditions including hypertension, cardiovascular disease, metabolic syndrome, Type 2 Diabetes and osteoporosis (Bailey et al., 2013). However, there are allergies related to milk consumption in humans, and this is the primary reason for limiting or avoiding consumption of dairy foods.

With the increase in production and consumption comes concern with the quality of the product reaching consumers, especially when this product is related to various human health problems such as cow's milk protein allergy (CMPA), an adverse immune response to dietary antigen in cow's milk (Mc Williams \& Collins, 2014).

One of the main milk proteins is casein, which is the second milk protein fraction to cause greater sensitivity in individuals. This group of proteins constitutes about $80 \%$ of all milk proteins, divided into four groups: s1 alpha, s2 alpha, beta and kappa. Casein contains proteins that when digested are transformed into opioid compounds known as $\beta$-casomorphins (BCM). $\mathrm{BCM}$ bonds with $\mathrm{A} 1$ allele of $\beta$-casein, and it is believed that the ingestion of this allele may cause allergies and other diseases to the human body. On the other hand, A2 allele of $\beta$-casein has no connections to such health problems. Some cow breeds have a higher expression of A2 $\beta$-casein and produce less allergenic milk.

CMPA is the most common type of food allergy and usually affects children, especially newborns. The overuse of cow's milk as a substitute for human milk has led to an increased incidence of this disease (Carvalho-Junior, 2001). In CMPA, the child's body does not recognize one or more of the cows' milk proteins (casein, alpha-lactalbumin and beta-lactoglobulin), leading to a reaction. In recent years, several companies have been devoted to applying molecular or genetic markers to the bovine milk agribusiness, since knowledge of genes is important for bio-economic characteristics in the production system, offering benefits to agribusiness.

Overall, allergies and intolerances appear from the body's biochemical inability to digest, absorb and metabolize a specific component. In the case of milk, lactose intolerance (LI) is the body's inability to digest lactose, due to the total or partial absence of an enzyme specialized in this action called lactase. On the other hand, allergy to cow's milk protein (CMPA) is characterized by immune reactions when the body comes in contact with cow's milk protein (Gasparin et al., 2010).

${ }^{1}$ Universidade Federal do Rio Grande do Norte-UFRN, Campus Universitário Lagoa Nova, Natal, RN, Brasil

${ }^{2}$ Instituto Federal de Educação, Ciência e Tecnologia do Rio Grande do Norte - IFRN, Campus Ipanguaçu, Ipanguaçu, RN, Brasil

*Corresponding author: stela_antas@yahoo.com.br 
Intolerance to lactose and CMPA are often confused since they are caused by the same food source, milk, and also because they have some similar symptoms such as diarrhea and cramping. Given this, differentiating between these two situations is essential, as being intolerant makes it necessary to exclude or only eat low amounts of foods containing lactose (depending on the degree of the intolerance), and in cow's milk allergy, the ingestion of any milk protein or foods containing fractions of it must be excluded to avoid triggering an allergic reaction.

Such facts have led researchers to study breeds and discover which have higher genotypes and $\mathrm{A} 1$ and $\mathrm{A} 2$ allele frequencies. Since then, those breeds presenting a greater amount of A1 allele began to produce A1 Milk is an allergenic milk that may cause diseases to predisposed people. Thus, breeds with higher amounts of A2 allele began to produce A2 milk, which does not cause diseases and can be ingested by people with CMPA.

Thus, the objective of this study was to conduct a review of available literature on cow's milk protein allergy and lactose intolerance.

\section{Cow's milk protein allergy (CMPA)}

\subsection{Overview}

Milk is considered a staple food for children and an essential supplement in the diet of adults, since it has a balanced composition of nutrients with optimal digestibility, resulting in a product with high biological value. However, its consumption, in some cases, is associated with adverse reactions, such as cow's milk protein allergy (CMPA) (Bahna, 2002). Currently, the term has been replaced by "adverse food reactions" - AFR (Reações Adversas aos Alimentos - RAA) in order to reduce confusion about definitions of each situation.

Adverse food reactions can be divided into two types: the first being toxic adverse reactions, which depend more on the substance ingested (e.g.: bacterial toxins present in contaminated food) or pharmacological properties of certain substances present in food (e.g.: caffeine in coffee, tyramine in matured cheeses) (Sampson, 2004), and the second being non-toxic adverse reactions, which depend on individual susceptibility and can be classified as non-immune-mediated (food intolerance) or immune-mediated (food hypersensitivity or food allergies). The many causes of these adverse reactions may involve different mechanisms, leading to the onset of a wide range of clinical symptoms (Tumas \& Cardoso, 2008).

Food allergy (FA) is a term used to describe adverse reactions to food, dependent of immune mechanisms, mediated or not by immunoglobulin E (IgE) and immunological cells. FAs mediated by IgE are characterized by rapid installation, and those which are non-mediated by IgE have later clinical manifestations (hours or days), making diagnosis difficult (Eigenmann et al., 1998).

Usually cow's milk, eggs, wheat and soy food allergies disappear in childhood, unlike allergies to peanuts, tree nuts and seafood that can be longer lasting and last the whole life (Eigenmann et al., 1998). This disease affects the immune system, triggering action mechanisms against the causative antigen, causing signs and symptoms after food ingestion. In the case of cow's milk allergy, the causative agent is mainly found in dairy/milk and its derivatives. The agents responsible for all of these reactions are cow's milk proteins, such as casein, $\beta$-lactoglobulin, $\alpha$-lactalbumin, serum albumin, and immunoglobulins (Gasparin et al., 2010).

Despite the body having the ability to digest milk proteins, they are sometimes not recognized by the immune system, thereby triggering the development/onset of allergies. This situation is diagnosed as cow's milk protein allergy, resulting in the need for nutritional therapy (Benhamou et al., 2009; Luiz et al., 2005).

Cow's milk protein allergy (CMPA) is the most common food allergy in early childhood, affecting $2 \%$ to $5 \%$ of the child population with less than three years of age (Huang \& Kim, 2012). It has a peak incidence at three months and is rarely observed after six months of age. However, the incidence is significantly less in infants who are exclusively breastfed, at a rate of about $0.5 \%$ to $1 \%$ (Helm, 2014). The fact that cow's milk proteins (CMP) constitute the first food antigens to be introduced into the infant diet may partly explain this food allergy being the most frequent and precocious (Vandenplas et al., 2007; Kneepkens \& Meijer, 2009; Orsi et al., 2009). The clinical presentation is generally moderate in infants, which can be explained by CMP concentration in breast milk (BM) being 100,000 times less than the concentration found in infant formulas (Table 1).

Another factor associated with food allergies and especially cow's milk protein allergy (CMPA) is the early contact with this food. At birth, the digestive system and the immune system of newborns are still maturing; the enteric enzymatic system and the immune system are not fully formed yet. The most ideal food for babies is breast milk. Small amounts of proteins and peptides consumed by the mother are passed through the milk and therefore the baby will slowly be in contact with the food they will consume in the future. This process is called tolerance development (Dias et al., 2009).

In developed countries, cow's milk protein allergy (CMPA) affects between $2 \%$ and $7.5 \%$ of children, especially in the first months of life. In a recent epidemiological study conducted in pediatric gastroenterologists' offices of the South and Southeast regions of Brazil, 7.4\% of 9,478 children were suspected of having a food allergy, and cow's milk protein allergy in $77 \%$ of cases. In this study, the incidence and prevalence of CMPA suspicion

Table 1. Composition of the main proteins in breast milk and cow's milk.

\begin{tabular}{ccc}
\hline Protein & Breast $(\mathrm{mg} / \mathrm{mL})$ & Cow $(\mathrm{mg} / \mathrm{mL})$ \\
\hline a-lactalbumin & 2.2 & 1.2 \\
a-s1-casein & 0 & 11.6 \\
a-s2-casein & 0 & 3.0 \\
$\beta$-casein & 2.2 & 9.6 \\
א-casein & 0.4 & 3.6 \\
r-casein & 0 & 1.6 \\
Immunoglobulins & 0.8 & 0.6 \\
Lactoferrin & 1.4 & 0.3 \\
$\beta$-lactoglobulin & 0 & 3.0 \\
Lysozyme & 0.5 & Traces \\
Serum albumin & 0.4 & 0.4 \\
Other & 0.8 & 0.6 \\
\hline
\end{tabular}


calculated by the diagnostic reported by surveyed physicians were $2.2 \%$ and $5.7 \%$, respectively (Luiz et al., 2005). Furthermore, the reported prevalence of CMPA varies dramatically between studies, which may be attributable to different methods being used for diagnosis or differences in the ages of the studied populations (Venter \& Arshad, 2011).

Several predisposing factors have been proposed, but so far none have been confirmed. There seems to be a genetic predisposition, as about two thirds of children with CMPA have a history of atopy in first degree relatives. Also, environmental factors such as neonatal antecedents that alter the formation of intestinal flora, as well as prematurity, antibiotic therapy early in life, or early and sporadic contact with CMP in utero through breast milk or through occasional formula administration to infants seem to cause CMPA predisposition. Exclusive breastfeeding for four to six months appears to be a protective factor, for not only CMPA but also other food allergies (Vandenplas et al., 2007; Kneepkens \& Meijer, 2009).

The pathophysiological mechanism by which food allergies develop involves processes of fundamental importance such as the permeability of the gastrointestinal tract barrier and individual genetic predisposition, in addition to antigens (protein of molecular weight between 10 and $70 \mathrm{kDa}$ ). The physiological immaturity of the digestive system inherent in the first two years of life and the immature immune system at this age are important factors in order to establish the development of CMPA in childhood.

Milk from other mammals (goats and sheep) are similarly antigenic to cow's milk, and so there is no advantage in their use as preventive to cow's milk protein allergy. It is noteworthy that $90 \%$ of children allergic to cow's milk protein also present an allergic reaction to goat and sheep milk, and that the association with a food allergy to beef is extremely rare (Eigenmann et al., 1998).

\subsection{Signs and symptoms}

Most children with CMPA develop symptoms before the first month of age, often during the first week of dairy introduction and it can affect several organs of the body, causing more than one symptom, or even symptoms in more than one organ. Approximately $50 \%$ to $70 \%$ of subjects have cutaneous symptoms, $50 \%$ to $60 \%$ gastrointestinal symptoms and $20 \%$ to $30 \%$ respiratory symptoms (North American Society for Pediatric Gastroenterology Hepatology and Nutrition, 2010).

The characteristic signs and symptoms result from immediate gastrointestinal hypersensitivity after allergen ingestion and can cause nausea, vomiting, abdominal pain and diarrhea, leading to weight gain deficit and malnutrition, also due to intestinal malabsorption or energy loss of food eliminated by vomiting and regurgitation. Some may present a rash, pruritus, angioedema, bronchospasm, oral allergy, eosinophilic esophagitis, gastroesophageal reflux, cramps, eosinophilic gastroenteropathy, enteropathy, enterocolitis, allergic colitis, chronic constipation, and skin and respiratory disorders (Vonk et al., 2003).

Morais \& Fagundes (2003) report that it is common for children in their first year of life to have diseases like CMPA and gastroesophageal reflux disease (GERD), often even interconnected.
Symptoms such as low birth weight and malnutrition, vomiting, hematemesis, constipation with pain, chronic diarrhea with malabsorption and rectal bleeding can result from GERD secondary to CMPA gastritis, although not being a very common expression of this pathology. They observed two cases in which children stopped receiving breast milk in the first three months of life, with symptomatic condition starting right away. After a final diagnosis, they were both diagnosed with hemorrhagic gastritis from cow's milk protein allergy.

\subsection{Milk proteins}

Milk provides high quality and proteins in significant amounts, providing an average of $3.5 \mathrm{~g}$ to $3 \mathrm{~g}$ of protein per $100 \mathrm{~g}$ of milk. After blood proteins, milk proteins are probably the most well characterized from the physico-chemical and genetic point of view. They have the advantage of being proteins from an animal source, being cheaper and possessing high biological value. They are used as ingredients in various food products, and individually they can display several beneficial functions to the organism, such as increased calcium absorption and immune functions, lowering blood pressure and the risk of cancer (Host, 2002).

Milk proteins are divided into multiple classes of polypeptide chains, the main one being: casein, beta-lactoglobulin and alpha-lactalbumin. According to Cortez et al. (2007), milk contains more than 20 protein components provided with different degrees of antigenic activity, and in several studies subjects allergic to milk showed that their sensitivity to each protein fraction follows frequencies shown in Table 2.

The casein group represents around $75 \%$ to $85 \%$ of milk proteins and nearly all of them are associated with calcium and phosphorus in micelles of 20 to $300 \mu \mathrm{m}$ in diameter that reflect light, creating the characteristic white color of milk. Because of their excellent nutritional value, caseins are used by many authors as the reference protein for assessing food protein quality. Although the major compounds of CMPA are supposedly found in casein fractions of $\beta$-lactoglobulin $(\beta-\lg )$ and $\alpha$-lactalbumin $(\alpha-l a)$, all milk proteins are potential allergens, including those present in smaller concentrations (Carvalho-Junior, 2001).

Some authors have shown that most of the 92 CMPA patients evaluated were susceptible to several proteins. Of those, only $26 \%$ were mono-sensitive; $17,22,20$ and $15 \%$ of patients were sensitive to two, three, four and five allergens, respectively. The main proteins indicated in this study as having higher allergen potential in weight were casein, $\beta$-lactalbumin and a-lactalbumin, since 65,61 and $51 \%$ of patients were specifically

Table 2. Sensitization percentage of protein fractions.

\begin{tabular}{cc}
\hline Protein fraction & \% of sensitive individuals \\
\hline Beta-lactoglobulin & $66-82$ \\
Casein & $43-60$ \\
Alpha-lactalbumin & $41-53$ \\
Bovine Serum Globulin & 27 \\
Bovine Serum Albumin & 18 \\
\hline
\end{tabular}

Source: Cortez et al. (2007). 
sensitized by the aforementioned proteins, respectively. Some proteins present in small concentrations, such as bovine serum albumin, immunoglobulins and lactoferrin, also appear to have great importance in the process, since 43, 36 and 35\% of the patients were sensitive to these proteins, respectively (Cocco et al., 2007).

Casein acts as a potent allergen in CMPA where each different fraction (S1-, S2, $\beta$ - and $\kappa$-casein) can induce specific $\mathrm{IgE}$ responses. The largest phosphorylation sites appear to be a major allergen epitope in caseins and changes in these regions could affect the allergenicity of these (Naspitz et al., 2004). According to a study by Reis \& Vaz (2004), caseins were predominantly allergenic and immunogenic in patients with IgE-mediated CMPA compared to whey proteins.

Caseins are divided into four groups: s1 alpha (30\%-46\% of caseins), s2 alpha (8\%-11\%), beta (25\%-35\%) and kappa (8\%-15\%) and are encoded by genes present on the bovine chromosome 6 (Vercesi, 2011). In the 1970s, the amino acid sequence of the four caseins was determined. In this same decade, the genetic variants from each of them started to be discovered, differing from each other by an amino acid or a group of them. All caseins contain high amounts of non-polar amino acids, and likely reduced solubility in water, but the relative abundance of phosphate groups, the lack of sulfur, and the presence of a carbohydrate moiety make them very polar (Ordóñez, 2005).

Ordóñez (2005) also explains that caseins are rich in proline. The $\alpha$-s1 contains 17 residues, the $\alpha$-s2 10 , the $\beta 35$ and the $\kappa 20$ residues. The high number of proline residues makes the structure degree in these proteins smaller than in others. The least organized is beta-casein, where $70 \%$ of its residues do not form a secondary structure.

Beta-casein is the second most abundant protein in milk, in addition to being crucial for casein micellar structure. It has a polymorphic condition/state and is composed of 209 amino acids, which are divided into 13 variants: A1, A2, A3, B, C, D, E, F, H1, H2, I and G. Variants A1 and A2 are described as the most common beta-casein allelic variants in dairy cows (Farrell et al., 2004; Vercesi, 2011). Due to its polymorphic nature and association with fat and milk protein, they have attracted several efforts in evaluating their locus as a main peculiarity for industry (Kucerova et al., 2006).

$\mathrm{A} 1$ and $\mathrm{A} 2$ variants are differentiated by the change of one nucleotide in the position 67 of the chain (A1 histidine and A2 proline). Studies have indicated that initially the entire bovine population contained only the A2 allele, and A1 allele was created from a mutation (Vercesi, 2001). Due to the subtle differences in their structures, these beta-casein variants are digested differently. For A2 beta-casein, the enzymatic hydrolysis does not occur or occurs at very low rates, producing the peptide beta-casomorphin-9 (BCM-9). In contrast, the digestion of A1 beta-casein can produce the exogenous opioid peptide called beta-casomorphin-7 (BCM-7) (European Food Safety Authority, 2009; Sodhi et al., 2012).

It is believed that BCM-7 is a major cause for health related problems in humans (Trompette et al., 2003), which is why the consumption of A1 Milk has been associated with a large increase in diseases such as diabetes mellitus type I (Thorsdottir et al., 2000), coronary disease (McLachlan, 2001), arteriosclerose (Tailford et al., 2003), sudden infant death syndrome (Sun et al., 2003), schizophrenia and autism (Woodford, 2008), as well as allergies. On the other hand, Kaminski et al. (2007) claim that the A2 allele has no connection with such health problems. According to Vercesi (2001), CSN2 is encoded by genes present in the bovine chromosome 6 .

\subsection{Dairy breeds and polymorphisms in the $\beta$-casein gene}

A study involving Norwegian Red dairy cows (Nilsen et al., 2009) found favorable genetic association of the A2 allele with higher milk and protein production. A similar result was obtained by Olenski et al. (2010), who found a positive association between the A2 allele and the genetic merit for milk and protein production, and a negative association between this gene and the genetic value for the fat percentage in Dutch cows in Poland. Therefore, on top of adding value to human health, A2 allele beta-casein may be associated with higher production of milk and protein in cattle. New Zealand currently has dairy farms producing only milk with A2 protein (called A2 milk), due to assumptions that this variant is not harmful to human health, as opposed to variant A1 (Vercesi, 2001).

In Brazil, about $80 \%$ of the milk is produced by crossbred animals from mating taurine (predominantly Dutch) with zebu (predominantly Gyr) breeds. Of the total semen produced and marketed in Brazil for dairy production, the Gyr breed is responsible for about $48 \%$. This fact led researchers to study all breeds and discover which produced larger amounts of A1 and A2 milk (Garcia, 2009).

A genetic study conducted in the University of São Paulo in São Carlos demonstrated that zebu breeds are almost entirely still producing A2 milk (close to $100 \%$ ) and have not been affected by this genetic mutation. In addition to the known characteristics of rusticity and external parasite resistance, there is now another advantage; Gyr milk is non-allergenic (Garcia, 2009).

In a study conducted by Lima (2014) with flocks of Gyr and Guzerá, a high frequency of A2 allele and A2A2 genotype was observed in $\beta$-casein genes in the evaluated cattle; they also claim that the selection of Zebu breeds with this high frequency allele is emerging as a viable alternative for the production of non-allergenic milk.

In taurine breeds (European), only the Guernsey breed, a once well-established dairy breed in Brazil that unfortunately became extinct due to several factors but now has increasing levels worldwide, exclusively produces A2 milk; the Jersey breed is in second place with $75 \%$ of A 2 milk and $25 \%$ of A 1 allergenic milk; and the Holstein breed, with 50\% A1 milk and 50\% A2 milk (Lima, 2014).

\section{Lactose intolerance}

\subsection{Overview}

Lactose intolerance is intolerance to the most common carbohydrate in milk affecting all age groups (Matthews et al., 2005). It could be described as an intestinal mucosa disorder that 
incapacitates the digestion of lactose due to the deficiency of an enzyme called lactase (Heyman, 2006; Qiao et al., 2011). This is a generic term that refers to the varied clinical manifestations caused by adverse reactions triggered by food.

This pathology is characterized by a set of clinical symptoms accompanying lactose maldigestion, representing $2 \%$ to $8 \%$ of its solid portion. This compound belongs to the group of carbohydrates included in the group of sugars classified as a disaccharide. The "sugar in milk," a popular name for lactose, has its molecule formed by two simple sugars, which are glucose and galactose joined by a glycosidic linkage which facilitates the absorption of this main milk glycide and is used as an energy source by the body (Morais \& Fagundes, 2003).

Lactose is present in several types of milk, and all mammals, including humans, when born under normal conditions are able to digest this sugar. However, about $75 \%$ of the world population suffers from lactose intolerance, where the incidence in adults is less than $20 \%$ (Swagerty et al., 2002).

According to Jellema et al. (2010), Epidemiological studies show that the populations which depended on livestock in their early days much more than agriculture, and those that were major consumers of milk and dairy products in general, had a lower prevalence of lactose intolerance than those who depended more on agriculture to survive, as presented in Table 3.

Ethnic groups such as blacks, Hispanics and Asians are more likely to develop this intolerance (Swallow et al., 2001). Studies conducted in Brazil using lactose overload (50 g/d) in several individuals have shown that $70 \%$ of them presented different degrees of lactose intolerance (Semrad \& Powell, 2008).

Moreover, some studies have shown that extreme age groups, infants and the elderly are also often affected, rarely being lactose intolerant from birth (Semrad \& Powell, 2008). Most newborns have lactase when they are born and can digest lactose as infants. If an infection or food allergy affects the small intestine, the child can develop lactose intolerance, causing a reduction in lactase. Usually this damage is temporary, but it can take weeks or even months until the child can tolerate milk and dairy products again. Children naturally start to produce less lactase at ages 3-6 than in the first two years of life. In some children the production continues to decline, or may cease altogether. Symptoms of lactose intolerance often appear in adolescence or early adulthood (Swallow et al., 2001).

\subsection{Lactose}

Lactose, commonly known as milk sugar, is a disaccharide composed of glucose and galactose formed by the mammary glands of mammals through glucose to supply the carbohydrate component during lactation, and is the same found in cow's milk, human breast milk and all other mammals (Lomer et al., 2008). Therefore, there is no possibility of an "allergy to lactose" happening from the lack of specificity or for it being a non-protein component. Its concentration in milk varies depending on the type of mammal; in cow's milk the average is $7 \%$.

This disaccharide is hydrolyzed by the intestinal enzyme $\beta$-D-galactosidase or lactase, releasing monosaccharide components
Table 3. Primary adult hypolactasia prevalence in different populations.

\begin{tabular}{|c|c|c|}
\hline Country & Prevalence (\%) & Method \\
\hline Germany & 14.8 & $\mathrm{BH}$ \\
\hline Austria & 20.1 & $\mathrm{BH}$ \\
\hline Brazil (white) & 57.0 & G \\
\hline Brazil (Terenas Indians) & 89.3 & $\mathrm{BH}$ \\
\hline Brazil (Japanese) & 100.0 & G \\
\hline Brazil (mulattos) & 57.0 & G \\
\hline Brazil (Negroes) & 80.0 & G \\
\hline China & 87.3 & G \\
\hline Estonia (Finnish-background) & 24.8 & G \\
\hline France & 23.4 & $\mathrm{BH}$ \\
\hline Hungary & 37.0 & G \\
\hline India (North) & 67.5 & G \\
\hline India (South) & 86.8 & G \\
\hline Italy & 51.0 & $\mathrm{BH}$ \\
\hline Japan (adults) & 89.0 & $\mathrm{BH}$ \\
\hline Jordan (Bedouin) & 24.0 & $\mathrm{BH}$ \\
\hline Jordan (West) and Palestine & 75.0 & $\mathrm{BH}$ \\
\hline Russia (Northeast) & 35.6 & G \\
\hline Siberia (Khants) & 94.0 & G/T \\
\hline Somalis & 76.0 & $\mathrm{BH}$ \\
\hline Sudan (Béja tribe. farmers) & 16.8 & $\mathrm{BH}$ \\
\hline Sudan (Nilotis tribe. farmers) & 74.5 & $\mathrm{BH}$ \\
\hline Sweden (Caucasian children) & 10.0 & G \\
\hline Sweden (non-Caucasian children) & 66.0 & G \\
\hline Sweden (Caucasian elderly) & 5.0 & G \\
\hline Tuareg & 12.7 & $\mathrm{BH}$ \\
\hline Turkey & 71.3 & $\mathrm{BH}$ \\
\hline
\end{tabular}

${ }^{1}$ Breath hydrogen test $(\mathrm{BH})$. Genetic $(\mathrm{G})$ and Glycemia/Tolerance $(\mathrm{G} / \mathrm{T})$. Source: Jellema et al. (2010).

into the bloodstream for absorption. Galactose is enzymatically converted into glucose, which is the main metabolic fuel of many tissues. The lactase activity is high during the neonatal period, but it declines during weaning (Matthews et al., 2005).

When lactose reaches the intestinal lumen, it must be hydrolyzed into monosaccharides by lactase, which is an endo-enzyme present in the brush border membrane of the intestinal mucosa (epithelial cells of the intestinal lining) (Heyman, 2006). Intestinal disaccharides are synthesized by polysomes of the rough endoplasmic reticulum of enterocytes. They migrate to the Golgi apparatus where glycosylation is completed. Then they are transported in Golgi vesicles to the top of the membrane of mature enterocytes of small intestine villi, where they are attached and become more vulnerable to attacks than other disaccharides. The gene responsible for the lactase synthesis is located on chromosome 2 (where mutations may occur interfering with the disaccharide tolerance) (Tevês et al., 2001).

The products of the lactase enzyme on lactose (glucose and galactose) are absorbed by the mucosa of the small intestine. A small amount of carbohydrates may not be digested by enzymes and reach the colon intact, thereby suffering fermentation by local bacterial flora, and with the production of short chain fatty acids (butyric acid, propionic acid, acetic acid), and gases $\left(\mathrm{CO}_{2}\right.$ and $\left.\mathrm{H}_{2}\right)$. The products of carbohydrate bacterial fermentation are absorbed 
in the colon and the calories are used up, thus contributing to the maintenance of the energy balance. This process is known as colonic rescue of carbohydrates (Tevês et al., 2001).

Under normal conditions, lactase is present in distal cells of the intestinal mucosa villi to perform lactose digestion. In deficiencies when disaccharidase activity is low, the events in the colon are accentuated by a higher rescuing of products that could have toxic effects to the organism and increased production of short chain fatty acid (SCFA), $\mathrm{H}_{2}$ and $\mathrm{CO}_{2}$, which play an important role in clinical manifestations (rashes, flatulence, bloating and abdominal pain), since they cause intestinal distension. The undigested lactose increases the osmotic load in the digestive tract, which adds to the clinical symptoms of lactose intolerance. The lactic acid produced by the microorganisms is osmotically active and pull water as well as undigested lactose, into the intestines resulting in diarrhea (Matthews et al., 2005).

The presence of osmotically higher content than intestinal lumen mucosal cells osmolarity determines the passage of water and, to a lesser extent of electrolytes of these cells to the enteral light in order to equalize osmotic pressure. Thus, large amounts of carbohydrates, whether digested or not, retain large amounts of water when they are not absorbed into the intestinal lumen in attempting isotonicity. When the amount of electrolytes lost is lower than the water, evacuations tend to be liquid (Swagerty et al., 2002).

The absorption of glucose and galactose is done at different speeds. The determining factor for maximum speed of lactose absorption depends on the amount of lactase present in the intestinal mucosa. Monosaccharides go through the mucosa and are actively transported into the bloodstream. Both glucose and galactose depend on sodium to be transported. When they are in the bloodstream, they travel through the portal vein to the liver where they are metabolized (Guerra, 2011).

Although lactase levels are normal in infancy, in adulthood these individuals start to present low levels of this enzyme. This decrease of quantity and the intestinal lactase activity is determined by genetic factors. However, it also is influenced by environmental factors such as the presence of malnutrition, parasites, intestinal infections and alcoholism. Moreover, in some cases it may represent an adaptive response to the decrease of dairy product intake (Guerra, 2011).

\subsection{Signs and Symptoms of Lactose Intolerance}

Signs and symptoms of lactose intolerance are similar to any other specific enzyme deficiency. They include abdominal pain, bloating in the abdomen, flatulence, diarrhea, intestinal noises, and particularly in the young, vomiting. Abdominal pain may be crampy and is often located in the periumbilical region or lower quadrant. The intestinal noises may be heard during the physical examination and by the patient. The stools are usually bulky, frothy and watery. An important feature is that these individuals usually do not lose weight, even with chronic diarrhea mentioned above. In some cases, gastrointestinal motility is reduced and the subjects may have constipation, possibly as a result of methane production (Guerra, 2011).
Even when only lactose absorption is directly damaged by lactase deficiency, the resulting diarrhea can be intense enough to remove other nutrients before they can be absorbed and may cause malnutrition, especially in children. Lactose intolerance is also responsible for many systemic symptoms, such as headaches and dizziness, loss of concentration, short term memory difficulty, muscle and joint pain, severe tiredness, various allergies, cardiac arrhythmia, oral ulcers, sore throat and increased frequency of urination. In the presence of systemic symptoms, it is necessary to evaluate if in fact they result from lactose intolerance, whether they are coincident symptoms or result from allergy to cow's milk protein (which affects up to $20 \%$ of patients with symptoms suggestive of lactose intolerance) (Guerra, 2011).

There is a wide variability of symptoms among patients with lactose intolerance. The factors responsible for this variability include the osmolality and food fat content in which the sugar is ingested, stomach emptying, sensitivity to abdominal distension produced by the osmotic load of the lactose which is not hydrolyzed in the upper small intestine, intestinal transit and the colon's response to the carbohydrate load. Generally, foods with a high fat content and osmolality decrease gastric emptying and reduce the severity of symptoms induced by lactose (Jellema et al., 2010).

Depending on the intensity of lactose intolerance, net losses from diarrhea can be very large and result in major loss of electrolytes, particularly sodium and potassium, as well as dehydration. Hyponatremia may be aggravated by inadequate replacement at the expense of poor liquids or being exempt of sodium. However, in osmotic diarrhea, the fluid losses are greater than sodium, as other molecules draw water into the intestinal lumen. Thus, hypernatremia occurs which increases when the replacement is also incorrect, providing excess sodium with respect to water. Hypernatremic dehydration is found in children, especially under 2 years of age and may endanger the life of the patient when treatment is not done with balanced solutions (Jellema et al., 2010).

The amount of lactose ingested in order for it to trigger symptoms vary for each individual depending on the dose of lactose ingested, the degree of lactase deficiency, and type of food with which the lactose has been consumed, and the severity of the symptoms depends on the amount of lactose that the person can tolerate (Tumas \& Cardoso, 2008).

\section{Differences between the pathologies}

Clinical manifestations of milk protein allergy related to the digestive tract are very similar to those of lactose intolerance, which can easily lead to misdiagnosis. However, CMPA can cause skin lesions (atopic eczema) and also respiratory symptoms, which does not occur in lactose intolerance. Lactose intolerance, in turn, is purely a matter of digestion and absorption, with no immunologic mechanism involved in the pathophysiology, and it affects adults more frequently than children. Its evolution can be transient or definitive (Tumas \& Cardoso, 2008). The difference of the characteristics between these two pathologies is described in Table 4. 
Table 4. Differentiating characteristics between lactose intolerance and cow's milk protein allergy.

\begin{tabular}{lll}
\hline \multicolumn{1}{c}{ Lactose intolerance } & \multicolumn{1}{c}{ Cow's milk protein allergy } \\
\hline Age of onset & $\begin{array}{l}\text { More common in adults; there is a } \\
\text { natural tendency to develop LI in the } \\
\text { ageing process. }\end{array}$ & More common in children, especially infants. \\
\hline Clinical & $\begin{array}{l}\text { Diarrhea, cramping, abdominal } \\
\text { distension, nausea, bloatedness. May } \\
\text { appear minutes or hours after ingesting } \\
\text { food with lactose. }\end{array}$ & $\begin{array}{l}\text { Vomiting, cramping, abdominal pain, constipation, bloody stools, growth deficiency, } \\
\text { gastroesophageal reflux, dermatitis, asthma, rhinitis. May appear minutes or days after the } \\
\text { ingestion of milk or dairy. }\end{array}$ \\
\hline Prognosis & $\begin{array}{l}\text { It can evolve as temporary or } \\
\text { permanent. Most people with LI tolerate } \\
\text { small amounts of lactose. }\end{array}$ & 50\% of cases evolve into being cured by 12 months of age, and 90\% by 3 years of age. \\
\hline Source: Tumas \& Cardoso (2008).
\end{tabular}

Even with so much information available, many people still have difficulties in identifying the differences between lactose intolerance and allergy to milk protein. These doubts do not occur only with patients; many health professionals have trouble with concluding the diagnosis, generating nutritional complications in patients.

\section{Conclusion}

CMPA is totally linked to immune responses, since it is the defense to a protein not recognized by the body; lactose intolerance is a metabolic disorder caused by an absence of lactase, and thus has the characteristic of not being able to absorb the sugar present in cow's milk. These conditions are similar in some points, such as in the symptoms, as both have gastrointestinal reactions. However, with the allergy there can be no intake of the milk protein, as its consumption is only recommended after treatment. In LI, deprivation occurs also from milk, but some people can consume some types of dairy products, as long as lactose has been previously hydrolyzed.

However, independent of the condition, there can be no diagnostic errors as there will be implications on the nutritional, physical and psychological state of the patient. Because of this, it is essential that professionals know how to recognize the most appropriate way possible to not submit the patient to greater losses exacerbating the responses to the aggressor. So professional nutritionists need to analyze and adapt to the nutrient intake, optimizing the availability of macro and micronutrients necessary for the maintenance and good health.

\section{References}

Bahna, S. L. (2002). Cow's milk allergy versus cow milk intolerance. Annals of Allergy, Asthma \& Immunology, 89(6, Suppl 1), 56-60. http://dx.doi.org/10.1016/S1081-1206(10)62124-2. PMid:12487206.

Bailey, R. K., Fileti, C. P., Keith, J., Tropez-Sims, S., Price, W., \& AllisonOttey, S. D. (2013). Lactose intolerance and health disparities among African Americans and Hispanic Americans: an updated consensus statement. Journal of the National Medical Association, 105(2), 112127. PMid:24079212.
Benhamou, A. H., Tempia, M. G. S., Belli, D. C., \& Eigenmann, P. A. (2009). An overview of cow's milk allergy in children. Swiss Medical Weekly, 139(21-22), 300-307. PMid:19492195.

Carvalho-Junior, F. F. (2001). Apresentação clinica da alergia ao leite de vaca em sintomatologia respiratória. Jornal Brasileiro de Pneumologia, 1(1), 17-24.

Cocco, R. R., Camelo-Nunes, I. C., Pastorino, A. C., Silva, L., Sarni, R. O. S., \& Rosário, N. A. Fo. (2007). Abordagem Laboratorial no Diagnóstico da Alergia Alimentar. Revista Paulista de Pediatria, 25(3), 258-265.

Cortez, A. P. B., Medeiros, L. C. S., Speridião, P. G. L., Mattar, R. H. G. M., \& Fagundes, U. F. No. (2007). Conhecimento de pediatras e nutricionistas sobre o tratamento da alergia ao leite de vaca no lactente. Revista Paulista de Pediatria: Orgao Oficial da Sociedade de Pediatria de Sao Paulo, 25(2), 106-113.

Dias, A., Santos, A., \& Pinheiro, J. A. (2009). Persistence of cow's milk allergy beyond two years of age. Allergologia et Immunopathologia, 38(1), 8-12. PMid:19853359.

Eigenmann, P. A., Sicherer, S. H., Borkowski, T. A., Cohen, B. D., \& Sampson, H. A. (1998). Prevalence of IgE-mediated food allergy among children with atopic dermatitis. Pediatrics, 101(3), 1-8. PMid:9481027.

European Food Safety Authority - EFSA. (2009). Review of the potential health impact of $\beta$-casomorphins and related peptides (Scientific Report, pp. 8-107). Parma: EFSA.

Farrell, H. M. Jr, Jimenez-Flores, R., Bleck, G. T., Brown, E. M., Butler, J. E., Creamer, L. K., Hicks, C. L., Hollar, C. M., Ng-Kwai-Hang, K. F., \& Swaisgood, H. E. (2004). Nomenclature of the proteins of cow's milk-sixth revision. Journal of Dairy Science, 87(6), 1641-1674. http:// dx.doi.org/10.3168/jds.S0022-0302(04)73319-6. PMid:15453478.

Garcia, J. L. M. O leite A. 2009. Retrieved from: http://girbrasilartigos. blogspot. com.br/2009/04/o-leite.html

Gasparin, F. S. R., Teles, J. M., \& Araújo, S. C. (2010). Alergia à proteína do leite de vaca versus intolerância à lactose: as diferenças e semelhanças. Revista Saúde \& Pesquisa, 3(1), 107-114.

Guerra, S. N. P. P. (2011). Intolerância à lactose. In Anais da $68^{a}$ edição do curso Nestlé de atualização em Pediatria, Curitiba, Brasil.

Helm, N. (2014). Promoting breastfeeding in infants with cow's milk protein allergy: a case study. Pediatric Nursing, 40(5), 253-256. PMid:25929118. 
Heyman, M. B. (2006). Lactose Intolerance in Infants, Children and Adolescents. Pediatrics, 118(3), 1279-1286. http://dx.doi.org/10.1542/ peds.2006-1721. PMid:16951027.

Host, A. (2002). Frequence of cow's milk allergy in childhood. Annals of Allergy, Asthma \& Immunology, 89(6, Suppl 1), 33-37. http://dx.doi. org/10.1016/S1081-1206(10)62120-5. PMid:12487202.

Huang, F., \& Kim, J. S. (2012). IgE-mediated cow's milk allergy in chil- dren. Pediatric Allergy and Immunology, 12(6), 630-640. PMid:22847747.

Jellema, P., Schellevis, F. G., Van Der Windt, D. A. W. M., Kneepkens, C. M. F., \& Van Der Horst, H. E. (2010). Lactose malabsorption and intolerance: a systematic review on the diagnostic value of gastrointestinal symptoms and self-reported milk intolerance. QJM, 103(8), 555-572. http://dx.doi.org/10.1093/qjmed/hcq082. PMid:20522486.

Kaminski, S., Cieslinska, A., \& Kostyra, E. (2007). Polymorphism of bovine beta-casein and its potential effect on human health. Journal of Applied Genetics, 48(3), 189-198. http://dx.doi.org/10.1007/ BF03195213. PMid:17666771.

Kneepkens, F. C. M., \& Meijer, Y. (2009). Clinical practice. Diagnosis and treatment of cow's milk allergy. European Journal of Pediatrics, 168(8), 891-896. http://dx.doi.org/10.1007/s00431-009-0955-7. PMid:19271238.

Kucerova, J., Matějíček, A., Jandurová, O. M., Sørensen, P., Němcová, E., Štípková, M., Kott, T., Bouška, J., \& Frelich, J. (2006). Milk protein genes CSN1S1, CSN2, CSN3, LGB and their relation to genetic values of milk production parameters in Czech Fleckvieh. Czech Journal of Animal Science, 5(6), 241-247.

Lima, T. C. C. (2014). Polimorfismo no gene da beta-casein em rebanhos zebuínos leiteiros no estado do Rio Grande do Norte (Dissertação de mestrado). Universidade Federal do Rio Grande do Norte, Natal.

Lomer, M. C. E., Parkes, G. C., \& Sanderson, J. D. (2008). Review article: lactose intolerance in clinical practice - myths and realities. Alimentary Pharmacology \& Therapeutics, 27(2), 93-103. http:// dx.doi.org/10.1111/j.1365-2036.2007.03557.x. PMid:17956597.

Luiz, V. F. C., Speridião, P. G. L., \& Fagundes, U. F. No. (2005). Terapia nutricional nas intolerâncias e alergias alimentares. Electronic Journal of Pediatric Gastroenterology. Nutrition and Liver Diseases, 9(1), 3-12.

Matthews, S. B., Waud, J. P., Roberts, A. G., \& Campbell, A. K. (2005). Systemic lactose intolerance: a new perspective on an old problem. Postgraduate Medical Journal, 81(953), 167-173. http://dx.doi. org/10.1136/pgmj.2004.025551. PMid:15749792.

McLachlan, C. N. (2001). Beta-casein A1, ischaemic heart disease mortality, and other illnesses. Medical Hypotheses, 56(2), 262-272. http://dx.doi.org/10.1054/mehy.2000.1265. PMid:11425301.

McWilliams, L. M., \& Collins, A. D. (2014). Cow's milk allergy. In I. R. Mackay, N. R. Rose, D. K. Ledford \& R. F. Lockey. Encyclopedia of medical immunology: allergic diseases (pp. 191-194). New York: Springer.

Morais, M. B., \& Fagundes, U. F. No. (2003). Alergia alimentar. In F. A. Lopez \& A. L. D. Brasil (Eds.), Nutrição e dietética em clinica pediátrica (pp. 210-219). São Paulo: Atheneu.

Naspitz, C. K., Sole, D., Aguiar, M. C., Chavarria, M. L., Rosario, N. Fo., Zuliani, A., Toledo, E. C., Barreto, B. A. P., \& Souza, L. S. (2004). Phadiatop ${ }^{\circledR}$ no diagnóstico de alergia respiratória em crianças: Projeto Alergia (PROAL). Jornal de Pediatria, 80(1), 217-222. PMid:15192765.

Nilsen, H., Olsen, H. G., Hayes, B., Sehested, E., Svendsen, M., Nome, T., Meuwissen, T., \& Lien, S. (2009). Casein haplotypes and their associations with milk production traits in Norwegian Red cattle. Genetics, Selection, Evolution., 41(24), 1-12.

North American Society for Pediatric Gastroenterology Hepatology and Nutrition - NASPGHAN. (2010). Intolerância à lactose em crianças. Washington: NASPGHAN.

Olenski, K., Kamiński, S., Szyda, J., \& Cieslinska, A. (2010). Polymorphism of the beta-casein gene and its association with breeding value for production traits of Holstein-Frisian bulls. Livestock Science, 131(1), 137-140. http://dx.doi.org/10.1016/j.livsci.2010.02.023.

Ordóñez, J. A. (2005). Tecnologia de alimentos: alimentos de origem animal. (Vol. 2). Porto Alegre: Artmed.

Orsi, M., Fernandez, A., \& Follett, F. R. (2009). Alergia a la proteína de la leche de vaca: Proposta de guia para manejo de lo niños con alergia a la proteína de la leche de vaca. Archivos Argentinos de Pediatria, 107(5), 459-467. PMid:19809770.

Reis, M. J., \& Vaz, M. B. A. (2004). IgE total e o diagnóstico de alergia na criança. Bioanálise, 1(1), 18-22.

Qiao, R., Huang, C., Du, H., Zeng, G., Li, L., \& Ye, S. (2011). Milk consumption and lactose intolerance in adults. Biomedical and Environmental Sciences, 24(5), 512-517. PMid:22108417.

Sampson, H. A. (2004). Update on food allergy. The Journal of Allergy and Clinical Immunology, 113(5), 805-819. http://dx.doi.org/10.1016/j. jaci.2004.03.014. PMid:15131561.

Semrad, C. E., \& Powell, D. W. (2008). Approach to the patient with diarrhea and malabsorption. In L. Goldman \& D. Ausiello (Eds.), Cecil medicine (pp. 1019-1042). Philadelphia: Saunders.

Sodhi, M., Mukesh, M., Kishore, A., Prakash, B., Kapil, R., Khate, K., Kataria, R. S., \& Joshi, B. K. (2012). Screening of taurine and crossbred breeding bulls for A1/A2 variants of $\beta$-casein gene. The Indian Journal of Animal Sciences, 82(1), 2-9.

Sun, Z., Zhang, Z., Wang, X., Cade, R., Elmir, Z., \& Fregly, M. (2003). Relation of beta casomorphin to apnea in sudden infant death syndrome. Peptides, 24(6), 937-943. http://dx.doi.org/10.1016/ S0196-9781(03)00156-6. PMid:12948848.

Swagerty, D. L., Walling, A. D., \& Klein, R. M. (2002). Lactose intolerance. American Family Physician, 65(9), 1845-1850. PMid:12018807.

Swallow, D. M., Poulter, M., \& Hollox, E. J. (2001). Intolerance to lactose and other dietary sugars. Drug Metabolism and Disposition: the Biological Fate of Chemicals, 29(4), 513-516. PMid:11259342.

Tailford, K. A., Berry, C. L., Thomas, A. C., \& Campbell, J. H. (2003). A casein variant in cow's milk is atherogenic. Atherosclerosis, 170(1), 13-19. http://dx.doi.org/10.1016/S0021-9150(03)00131-X. PMid:12957678.

Tevês, P. M., Medina, J. S., Espinoza, Z. G., \& Salgado, E. M. (2001). Análisis de la prueba de tolerancia a la lactosa. Revista de Gastroenterologia del Peru, 21(4), 282-286. PMid:11818989.

Thorsdottir, I., Birgisdottir, B. E., Johannsdottir, I. M., Harris, D. P., Hill, J., Steingrimsdottir, L., \& Thorsson, A. V. (2000). Different (beta-casein) fractions in Icelandic versus Scandinavian cow's milk may influence diabetogenicity of cow's milk in infancy and explain low incidence of insulin dependent diabetes mellitus in Iceland. Pediatrics, 106(4), 719-724. http://dx.doi.org/10.1542/peds.106.4.719. PMid:11015514.

Trompette, A., Claustre, J., Caillon, F., Jourdan, G., Chayvialle, J. A., \& Plaisancié, P. (2003). Milk bioactive peptides and b-casomorphins induce mucus release in rat jejunum. The Journal of Nutrition, 133(11), 3499-3503. PMid:14608064. 
Tumas, R., \& Cardoso, A. L. (2008). Como conceituar, diagnosticar e tratar a intolerância à lactose. Revista Brasileira de Clínica e Terapêutica, 34(1), 13-20.

Vandenplas, Y., Brueton, M., Dupont, C., Hill, D., Isolauri, E., Koletzko, S., Oranje, A. P., \& Staiano, A. (2007). Guidelines for diagnosis and management of cow's milk protein allergy in infants. Archives of Disease in Childhood, 92(10), 902-908. http://dx.doi.org/10.1136/ adc.2006.110999. PMid:17895338.

Venter, C., \& Arshad, C. H. (2011). Epidemiology of food allergy. Pediatric Clinics of North America, 58(2), 327-349, ix. http://dx.doi. org/10.1016/j.pcl.2011.02.011. PMid:21453805.
Vercesi, A. E. Fo. (2011). Identificação de alelos A1 e A2 para o gene da beta-caseins na raça Gir Leiteiro. Pesquisa e Tecnologia, 8(11), 91-96.

Vonk, R. J., Priebe, M. G., Koetse, H. A., Stellaard, F., Lenoir-Wijnkoop, I., Antoine, J. M., Zhong, Y., \& Huang, C. Y. (2003). Lactose intolerance: analysis of underlying factor. European Journal of Clinical Investigation, 33(1), 70-75. http://dx.doi.org/10.1046/j.1365-2362.2003.01099.x. PMid:12492455.

Woodford, K. (2008). A1 beta-casein, type 1 diabetes and links to other modern illnesses. Internacional Diabetes Federarion Western Pacific Congress, Wellington, New Zealand. 